\title{
PENERAPAN STANDAR ISO 9001 DAN ISO 14001 SECARA BERSAMAAN
}

\author{
Sumito \\ Abstrak
}

\begin{abstract}
ISO seri 9000 tentang sistem manajemen mutu pertama kali diterbitkan oleh organisasi standardisasi internasional (ISO) pada tahun 1987. Pada waktu itu ISO seri 9000 terdiri dari ISO 9001, ISO 9002, ISO 9003 dan ISO 9004. Dalam perkembangannya, pada tahun 1994 ISO 9000 seri tersebut diadakan revisi yang pertama dan selanjutnya pada tahun 2000 juga dilakukan revisi, sehingga hasilnya adalah ISO seri 9000:2000 yang terdiri dari ISO 9000, ISO 9001 dan ISO 9004. Sedangkan ISO 14001 tentang sistem manajemen lingkungan pertama kali diterbitkan pada tahun 1996. Kemudian dalam perkembangannya ISO 14001 juga mengalami revisi pada tahun 2004, sehingga terbitlah ISO 14001:2004. Kedua standar tersebut sudah sangat dikenal dan familiar di kalangan masyarakat industri/perusahaan dan juga pihak ketiga (dalam hal ini lembaga sertifikasi) baik di tingkat nasional, regional maupun internasional. Saat ini sudah banyak di dalam suatu organisasi atau industri yang telah menerapkan secara bersamaan dari kedua standar tersebut (ISO 9001 dan ISO 14001).
\end{abstract}

Kata kunci: sistem manajemen, penerapan, ISO 9001, ISO 14001, organisasi

\section{Abstract}

ISO 9000 series (Quality management system) the first issued by the International Organization for Standardization (ISO) in 1987. At that time ISO 9000 series consist of ISO 9001, ISO 9002, ISO 9003 and ISO 9004. In their developing, in 1994 the ISO 9000 series conducted the first revision, and then in the year 2000 also have been conducted revision of ISO 9000, so that the result become ISO 9000:2000. And ISO 9000:2000 standard consists of ISO 9000, ISO 9001 and ISO 9004. Meanwhile ISO 14001 (Environmental Management System) the first issued in 1996 and in developing ISO 14001 also has been revised in 2004, so that issued a new ISO 14001 standard that is ISO 14001:2004. For all those standards very recognized and familiar in organization/industries and also by third party organization (certification bodies) at the national, regional and international level. At present many organization or industries have been implementation of those standards (ISO 9001 and ISO 14001) incorporated within one organization or industry.

Key words: management system, implementation, ISO 9001, ISO 14001, organization

\section{PENDAHULUAN}

Berdasarkan hasil survei yang telah dilakukan oleh organisasi standardisasi internasional yaitu ISO (International Organization for Standardization) pada putaran ke-13 (2003) terhadap penerapan ISO 9001 dan ISO 14001 diseluruh dunia terlihat bahwa sampai dengan akhir Desember 2003 jumlah sertifikat ISO 9001:2000 (Sistem manajemen mutu) yang diterbitkan di seluruh dunia sebanyak 500125 sertifikat (149 negara).

Sedangkan untuk ISO 14001 (sistem manajemen lingkungan) terlihat bahwa sampai dengan Desember 2003 jumlah sertifikat yang telah diterbitkan di seluruh dunia sebanyak 66070 sertifikat (di 113 negara). Sayangnya bahwa dalam laporan hasil survei tersebut tidak diberikan informasi lebih rinci atau gambaran lebih konkrit, berapa sebetulnya jumlah organisasi/perusahaan yang memperoleh sertifikat ISO 9001 dan ISO 14001 di seluruh dunia tersebut. Karena hal ini bisa saja terjadi bahwa dalam satu perusahaan/industri dapat memperoleh sertifikat ISO 9001 dan ISO 14001. Namun demikian, sebagai ilustrasi dapat disampaikan bahwa dari hasil survei yang pernah dilakukan di Belanda, ternyata $80 \%$ dari organisasi yang memperoleh sertifikat ISO 14001 juga telah memperoleh sertifikat ISO 9001. Dari informasi tersebut kira-kira dapat diasumsikan bahwa di tingkat internasional, secara umum bahwa organisasi yang telah menerapkan ISO 14001 juga menerapkan ISO 9001 (ISO management system/Januari-Februari 2004).

Sebagai informasi tambahan bahwa disamping menerapkan standar ISO 9001 dan ISO 14001, ternyata banyak pula industri atau perusahaan yang juga menerapkan standar manajemen lain seperti OHSAS 18001 (Occupational Health and Safety Management System). Standar OHSAS 18001 bukan merupakan standar ISO, tetapi suatu standar yang dikembangkan dan disusun oleh suatu kelompok kerja internasional, dimana anggotanya terdiri dari wakil-wakil dari berbagai 
organisasi, seperti lembaga sertifikasi, asosiasi, badan standardisasi nasional, dan lain-lain. Karena OHSAS 18001 ini dianggap penting dan dibutuhkan oleh pasar dan karena standar ISOnya juga belum tersedia, sehingga standar OHSAS 18001 tersebut ditetapkan dan diterbitkan. Hingga saat ini OHSAS 18001 telah diterapkan di sekitar 50 negara dan juga telah diterjemahkan kedalam 25 bahasa diseluruh dunia.

Melihat banyaknya perusahaan yang telah menerapkan ISO 9001 dan ISO 14001 dalam satu industri/perusahaan, sehingga dalam kajian ini hanya difokuskan untuk mengkaji terhadap elemen-elemen persyaratan yang ada di standar ISO 9001 dan ISO 14001. Hal ini dilakukan karena pada prinsipnya kedua standar tersebut mempunyai dasar yang sama, sehingga keduanya dapat disatukan atau digabungkan menjadi satu standar sistem manajemen yaitu dengan mengakomodasi persyaratanpersyaratan yang ada dari kedua standar tersebut (ISO 9001 dan ISO 14001).

Dan upaya-upaya untuk mengintegrasikan beberapa standar ISO menjadi satu standar seperti ini telah dilakukan oleh ISO yaitu dengan digabungkannya standar ISO 10011-1, ISO 10011-2, dan ISO 10011-3 (untuk audit sistem manajamen mutu) dengan ISO 14010, ISO 14011 dan ISO 14012 (untuk audit sistem manajemen lingkungan) menjadi satu standar sistem manajemen terpadu yaitu ISO 19011. Standar ISO 19011 ini sebagai panduan untuk audit sistem manajemen mutu dan/atau lingkungan untuk menggantikan ISO 10011-1, 10011-2, 10011-3 dan ISO 14010, 14011 dan 14012 tersebut.

\section{TUJUAN}

Tujuan dari tulisan ini adalah untuk melihat hubungan dan keterkaitan antar elemen/butirbutir yang terdapat dalam standar ISO 9001 dan ISO 14001, sehingga para pengguna/penerap dari kedua standar tersebut dapat lebih mudah dan lebih efisien dalam menerapkan secara bersamaan.

\section{SASARAN}

Diterapkannya standar ISO 9001 dan ISO 14001 dalam suatu organisasi atau industri secara bersamaan dengan lebih mudah dan efisien.

\section{METODOLOGI}

Metodologi yang digunakan adalah dengan mengkaji dan membandingkan elemen/butir-butir yang ada dalam standar ISO 9001:2000 dan ISO 14001:2004. Dari hasil kajian ini sehingga dapat diketahui dengan jelas keterkaitan dan hubungan antara elemen/butir-butir yang ada dalam standar ISO 9001 dan ISO 14001 tersebut.

\section{ANALISIS DAN PEMBAHASAN}

\subsection{Karakteristik Dasar Sistem Manajemen}

Sampai saat ini berbagai standar sistem manajemen dan standar yang terkait berkembang sangat pesat yang mencakup bidang mutu, lingkungan, kesehatan dan keselamatan kerja, keamanan pangan, dan bahkan bidang sosial kemasyarakatan, misalnya konsep tanggung jawab sosial bagi korporate (CSR-Corporate Sosial Responsibility).

Secara umum bahwa standar-standar tersebut telah disepakati sebagai standar sistem manajemen. Dalam hal kegiatan standardisasi sistem manajemen ini, ISO telah membentuk panitia-panitia teknis atau Technical Committee (TC) yang beranggotakan para pakar di bidangnya. Untuk menangani ISO 9000, telah dibentuk TC 176 dan untuk menangani ISO 14001 ditangani oleh TC 207.

Menurut definisi yang diberikan dalam ISO 9000:2000, sistem manajemen mutu -Dasardasar dan kosakata bahwa sistem manajemen dapat dijelaskan sebagai seperangkat perencanaan keterkaitan dan interaksi untuk menyusun kebijakan dan tujuan yang diinginkan serta untuk mencapai tujuan tersebut. Pengaturan sebaiknya menjamin pengendalian yang sistematik dan peningkatan operasional organisasi dan proses yang lain. Jadi secara singkat dapat dikatakan bahwa sistem manajemen dapat digunakan untuk mengarahkan dan mengendalikan organisasi dalam hal mutu (ISO 9000:2000).

Sistem manajemen mempunyai suatu dimensi internal dan juga eksternal. Sebagai penyedia alat untuk organisasi guna mencapai tujuan organisasi secara konsisten, akan memberikan jaminan kepada pihak eksternal bahwa secara konsisten organisasi juga dapat memenuhi persyaratan, termasuk peraturan perundang-undangan. Dimensi internal dan eksternal mempunyai keterkaitan yang erat satu sama lain. Bagi organisasi/perusahaan itu sendiri dan pihak-pihak terkait, sistem manajemen yang 
efektif sebaiknya menjamin identifikasi, pengendalian dan meminimisasi resiko bisnis, sehingga dapat memaksimalkan peluang bisnis:

- Mengurangi resiko yang mencegah suatu organisasi untuk mencapai tujuan dan meningkatkan peluang yang memungkinkan untuk pencapaian sasaran;

- Mengurangi resiko kegagalan untuk memenuhi persyaratan eksternal dan kebutuhan dan harapan pemangku kepentingan (stakeholder), serta kemungkinan peningkatan persyaratannya;

- Peluang untuk meningkatkan kinerja organisasi guna meningkatkan kepuasan pelanggan dan menurunkan dampak lingkungan serta meningkatkan posisi pasar.

\subsection{Pendekatan Proses dan PDCA}

Sistem manajemen yang berkontribusi terhadap kinerja yang lebih baik dan selaras dengan kegiatan operasional sehari-hari dari suatu organisasi/perusahaan dapat didasarkan pada dua prinsip yang dikenal dengan "Deming Cycle" dan pendekatan proses. Deming Cycle menjelaskan urut-urutan langkah mulai dari Plan - Do - Check - Act (PDCA) yang diarahkan untuk mencapai suatu tujuan yang lebih efektif dan efisien. PDCA tersebut dapat dijelaskan sebagai berikut:

- Plan (perencanaan), organisasi harus menetapkan tujuan dan proses yang diperlukan untuk memberikan hasil yang sesuai dengan kebijakan organisasi.
- Do (pelaksanaan), organisasi harus menerapkan proses yang telah ditetapkan.

- Check (pemeriksaan), organisasi harus memantau dan mengukur proses terhadap kebijakan, tujuan, sasaran dan ketentuan lain serta melaporkan hasilnya.

- Act (tindakan), organisasi harus melaksanakan tindakan untuk meningkatkan kinerja sistem manajemen secara berkesinambungan.

Sistem manajemen yang efektif dan efisien mencakup perencanaan dan pelaksanaan untuk menjamin operasional dari langkah-langkah tersebut. Identifikasi secara sistematik dan manajemen proses dalam suatu organisasi, khususnya hubungan dan interaksi diantara proses disebut "pendekatan proses". Dengan membangun suatu sistem manajemen, organisasi memiliki proses yang sebaiknya ditetapkan sebagai titik awal. Pertimbangan terhadap proses, persyaratan sebaiknya ditetapkan untuk masukan dan luaran mereka, resiko dan peluang yang akan diases, identifikasi dan penerapan mekanisme pengendalian, pelaksanaan pengukuran kinerja dan hasil-hasil yang dianalisa serta peluang untuk peningkatan hal-hal yang teridentifikasi dan diterapkan.

Sistem manajemen yang didasarkan kepada kombinasi dua prinsip (model PDCA dan pendekatan proses) akan memberikan kepada organisasi dukungan nyata dalam pengendalian dan peningkatan kinerjanya, sebagaimana terlihat pada gambar 1 .

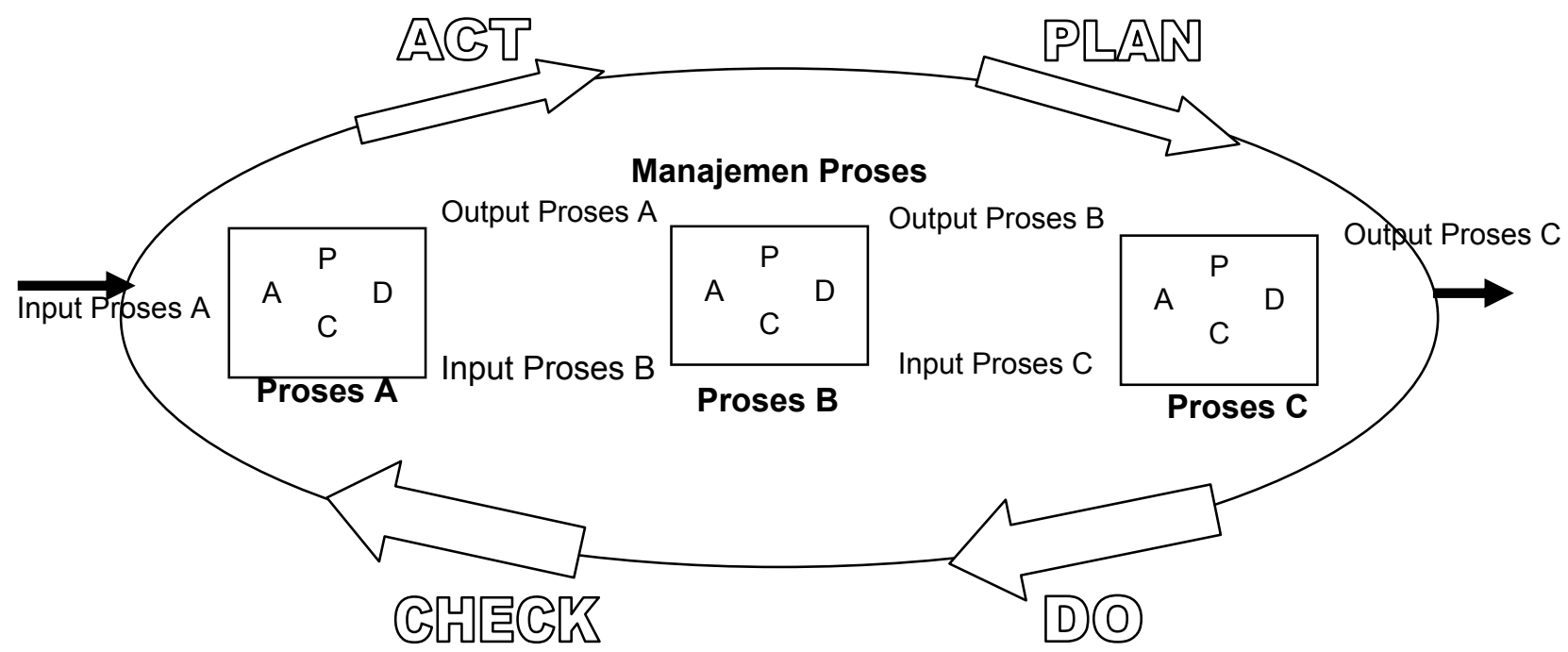

Gambar 1 Pendekatan Proses dan PDCA 


\subsection{Penerapan Standar Sistem Manajemen secara Bersamaan}

Suatu standar generik untuk sistem manajemen yang didasarkan pada prinsip-prinsip tersebut di atas belum ada. Apabila dikehendaki adanya suatu standar sistem manajemen tentunya bisa. Untuk itu, organisasi dapat mencakup bidangbidang manajemen yang relevan seperti mutu, lingkungan, kesehatan dan keselamatan kerja di dalam model manajemen tunggal menjadi sistem manajemen yang terintegrasi. Walaupun demikian, ISO dan organisasi lain telah mengembangkan standar sistem manajemen dan pedoman yang terpisah untuk bidang manajemen spesifik seperti mutu, lingkungan, kesehatan \& keselamatan kerja, keamanan pangan, dan lain-lain.

Oleh karena itu dengan adanya ISO 9001:2000 (sistem manajemen mutu) dan ISO 14001:2004 (sistem manajemen lingkungan) merupakan standar yang paling relevan yang dapat diterapkan secara bersamaan dalam suatu organisasi/perusahaan. Kedua standar tersebut mempunyai keselarasan yang sangat baik dengan prinsip-prinsip sistem manajemen sebagaimana telah dijelaskan pada bab sebelumnya. Disamping itu standar ISO 9001 dan ISO 14001 tersebut juga mempunyai dasar dan pendekatan yang sama, dimana kedua standar tersebut merupakan hasil dari proses konsensus yang telah disepakati secara internasional. Oleh karena itu dengan adanya standar sistem manajemen yang terintegrasi (ISO 9001 dan ISO 14001) akan menjadi alat yang penting bagi banyak industri/perusahaan dalam upaya untuk menerapkan kedua standar tersebut secara bersamaan dalam suatu organisasi atau industri.

\subsection{Dasar Umum Standar Sistem Manajemen}

Hal ini penting untuk diketahui, bagaimana kesesuaian standar untuk mendukung suatu pendekatan generik terhadap pengidentifikasian dan penilaian berbagai aspek kritis dan resiko dan juga peluangnya. Dasar ini juga penting sebagai pedoman dalam pengelolaan organisasi dan untuk peningkatan proses dan aktifitasnya. Oleh karena itu prinsip-prinsip dari dua standar yang dikaji dan dibandingkan satu dengan yang lain tersebut dengan mempertimbangkan :

- Pokok masalah untuk setiap sistem manajemen yang kemudian disebut dengan "bidang manajemen" yaitu mutu dan lingkungan;

- $\quad$ Sistem manajemen untuk mengelola yang berpengaruh;

- $\quad$ Focal point terhadap suatu organisasi yang akan mempengaruhi bidang manajemen: aspek lingkungan dan karakteristik mutu

Dalam Tabel 1 bawah ini disajikan hubungan antara konsep dan istilah dari ISO 9001:2000 dan ISO 14001:2004.

Tabel 1 Hubungan antara Konsep dan Istilah dari ISO 9001:2000 dan ISO 14001:2004

\begin{tabular}{|c|c|c|}
\hline Konsep & ISO 9001:2000 & ISO 14001:2004 \\
\hline Bidang manajemen & Mutu & Lingkungan \\
\hline Tujuan utama & Kepuasan pelanggan & Peningkatan kinerja lingkungan \\
\hline $\begin{array}{l}\text { Pihak-pihak terkait } \\
\text { utama (stakeholders) }\end{array}$ & $\begin{array}{l}\text { - Pelanggan } \\
\text { - Pemerintah regulator) }\end{array}$ & $\begin{array}{l}\text { - Pemerintah } \\
\text { - Pihak terkait dengan lingkungan }\end{array}$ \\
\hline Aspek kritis & $\begin{array}{l}\text { Karakteristik mutu (produk } \\
\& \text { proses) }\end{array}$ & $\begin{array}{l}\text { Aspek lingkungan } \\
\text { (kegiatan, produk dan jasa) }\end{array}$ \\
\hline $\begin{array}{l}\text { Persyaratan yang ter- } \\
\text { kait dengan aspek } \\
\text { kritis }\end{array}$ & $\begin{array}{l}\text { - Persyaratan pelanggan } \\
\text { - Persyaratan yang ter-kait } \\
\text { dengan maksud } \\
\text { penggunaan } \\
\text { - Persyaratan perundang- } \\
\text { undangan } \\
\text { - Persyaratan yang dite- } \\
\text { tapkan oleh organisasi }\end{array}$ & $\begin{array}{l}\text { - Persyaratan perundang-undangan } \\
\text { - Persyaratan pihak terkait } \\
\text { - Persyaratan dari hasil analisa resiko } \\
\text { (analisa aspek lingkungan) }\end{array}$ \\
\hline
\end{tabular}




\begin{tabular}{|l|l|l|}
\hline \multicolumn{1}{|c|}{ Konsep } & \multicolumn{1}{|c|}{ ISO 9001:2000 } & \multicolumn{1}{c|}{ ISO 14001:2004 } \\
\hline $\begin{array}{l}\text { Fokus kegiatan ma- } \\
\text { najemen }\end{array}$ & $\begin{array}{l}\text { Proses yang kritis ter- } \\
\text { hadap pemenuhan dari } \\
\text { karakteristik produk dan } \\
\text { kinerja organisasi secara } \\
\text { keseluruhan yang terkait } \\
\text { dengan mutu }\end{array}$ & $\begin{array}{l}\text { Operasi dan kegiatan yang terkait dengan } \\
\text { aspek lingkungan penting }\end{array}$ \\
\hline $\begin{array}{l}\text { Hasil-hasil kegagalan } \\
\text { manajemen }\end{array}$ & $\begin{array}{l}\text { Buruknya kinerja orga- } \\
\text { nisasi, termasuk produk } \\
\text { sehingga menyebabkan } \\
\text { pelanggan tidak puas }\end{array}$ & $\begin{array}{l}\text { Dampak yang membahayakan terhadap } \\
\text { lingkungan }\end{array}$ \\
\hline $\begin{array}{l}\text { Resiko terhadap } \\
\text { organisasi }\end{array}$ & $\begin{array}{l}\text { Organisasi tidak dapat } \\
\text { memenuhi persyaratan } \\
\text { pelanggan. Akibatnya } \\
\text { pelanggan tidak puas, } \\
\text { penurunan pangsa pasar } \\
\text { dan kerugian keuangan }\end{array}$ & $\begin{array}{l}\text { Kinerja lingkungan tidak dapat memenuhi } \\
\text { persyaratan perundang -undangan atau } \\
\text { persyaratan pihak terkait. } \\
\text { Akibatnya image organisasi jelek, adanya } \\
\text { kerugian keuangan, terjadinya tindak } \\
\text { kejahatan }\end{array}$ \\
\hline
\end{tabular}

Dari tabel 1 tersebut di atas terlihat bahwa standar ISO 9001 dan ISO 14001 mempunyai konsep dasar yang mirip (similar) yang digunakan sebagai alat untuk membangun kebijakan dan tujuan suatu organisasi di bidang tertentu. Kebijakan organisasi bertujuan untuk peningkatan kinerja lingkungan (ISO 14001), dan peningkatan kepuasan pelanggan melalui peningkatan mutu produk dan proses dari organisasi (ISO 9001).

Untuk mencapai kebijakan tersebut, suatu organisasi harus memenage aspek-aspek kritis dari proses, kegiatan dan produknya yang mempunyai dampak terhadap mutu dan lingkungan.

Menurut ISO 14001, penyebab dampak lingkungan potensial, misalnya aspek lingkungan penting sebaiknya organisasi menangani aspek tersebut dengan baik, sehingga kebijakan lingkungan dapat dicapai. Berdasarkan pada definisi yang terkait dengan mutu dalam ISO 9001:2000, ini jelas bahwa sistem manajemen mutu sebaiknya menjamin bahwa organisasi memenuhinya dan produknya sesuai dengan persyaratan, khususnya bagi pelanggan. Oleh karena itu organisasi sebaiknya menangani resiko setiap persyaratan yang tidak dipenuhi dengan pengawasan karakteristik mutu yang relevan dari proses dan produknya.

\subsection{Pendekatan Manajemen Resiko}

Dari dua standar tersebut, langkah-langkah umum manajemen resiko yang dapat diidentifikasi adalah sbb:

- Identifikasi resiko dan aspek kritis;
- Assesmen resiko dan prioritas;

- Penentuan persyaratan yang harus dipenuhi;

- Identifikasi dan implementasi mekanisme pengendalian.

ISO 14001 mensyaratkan untuk mengidentifikasi aspek lingkungan dan menentukan dampak penting terhadap lingkungan (butir 4.3.1). Disamping itu ISO 14001 juga mensyaratkan untuk menetapkan tujuan dan target yang akan dicapai (butir 4.3.3) serta juga mensyaratkan untuk mengendalikan operasional kegiatan yang terkait dengan aspek penting (butir 4.4.6).

Sedangkan ISO 9001:2000 mensyaratkan untuk menetapkan kriteria dan metode yang diperlukan untuk menjamin efektifitas operasi dan pengedalian suatu proses organisasi, misalnya menuju tingkat kinerja yang memenuhi persyaratan dan peningkatan kepuasan pelanggan (butir 4.1). Persyaratan yang terkait dengan produk (hasil proses organisasi) perlu ditetapkan (butir 7.2.1) dan yang terkait dengan karakteristik mutu produk perlu diawasi selama proses realisasi produk (butir 7).

\subsection{Aspek Kritis Manajemen Terpadu}

Aspek lingkungan tidak hanya terkait dengan kegiatan organisasi (proses fisiknya), tetapi juga untuk produk dan jasa yang dihasilkan serta untuk barang dan jasa yang digunakan. Dampak organisasi tergantung pada lingkungan melalui aspek lingkungannya dan menetapkan tingkat kinerja lingkungan sebaiknya mempertimbangkan persyaratan dan consern pemerintah dan pihak-pihak terkait lainnya. 
Karakteristik mutu tidak hanya terkait dengan produk organisasi, tetapi juga terkait dengan seluruh proses dalam organisasi yang dapat mempengaruhi kepuasan pelanggan.

Dalam hal ini organisasi harus mempertimbangkan pula persyaratan pelanggan. Apabila semua aspek kritis yang relevan teridentifikasi dan diases, maka organisasi membuat persyaratan internal dan eksternal yang sesuai dengan tujuan yang akan dicapai, suatu pendekatan generik untuk mengelola proses organisasi dapat diterapkan. Elemenelemen sistem manajemen generik diberikan dalam ISO Guide 72. ISO Guide 72 ini mengidentifikasi elemen sistem yang sebaiknya dicakup dalam standar sistem manajemen dan menunjukkan tugas dan struktur yang dalam setiap standar tersebut sesuai dengan elemenelemen.

Dalam tabel 2 di bawah ini dijelaskan tentang elemen sistem manajemen umum sebagaimana tercantum dalam ISO Guide 72.

Tabel 2 Elemen Sistem Manajemen Umum dalam ISO Guide 72

\begin{tabular}{|c|c|}
\hline Kategori utama & Elemen umum \\
\hline Kebijakan & Kebijakan dan prinsip-prinsip \\
\hline Perencanaan & $\begin{array}{l}\text { - Identifikasi kebutuhan, persyaratan dan analisis isu-isu kritis } \\
\text { - Pemilihan isu-isu penting } \\
\text { - Penetapan tujuan dan target } \\
\text { - Identifikasi sumber daya } \\
\text { - Identifikasi struktur, peranan, tanggung jawab, dan kewenangan } \\
\text { - } \text { Prganisasi } \\
\text { - Perencanaan pengendalian operasional }\end{array}$ \\
\hline $\begin{array}{l}\text { Penerapan dan } \\
\text { operasional }\end{array}$ & $\begin{array}{l}\text { - } \text { Pengendalian operasional } \\
\text { - } \text { Manajemen sumber daya manusia } \\
\text { - } \text { Kokumentasi dan pengedaliannya } \\
\text { - Hubungan dengan pemasok dan kontraktor }\end{array}$ \\
\hline Asesmen kinerja & $\begin{array}{l}\text { - } \quad \text { Pemantauan dan pengukuran } \\
\text { - } \quad \text { Analisis dan penanganan ketidaksesuaian } \\
\text { - } \quad \text { Audit sistem }\end{array}$ \\
\hline Perbaikan & $\begin{array}{ll}\text { - } & \text { Tindakan perbaikan dan pencegahan } \\
\text { - } & \text { Perbaikan yang berkesinambungan } \\
\end{array}$ \\
\hline $\begin{array}{l}\text { Kaji ulang manaje- } \\
\text { men }\end{array}$ & Kaji ulang manajemen \\
\hline
\end{tabular}

ISO Guide 72 tidak menetapkan model spesifik mengenai standar sistem manajemen yang sebaiknya diacu. Oleh karena itu model generik untuk mengintegrasikan sistem manajemen dapat mengacu pada prinsip-prinsip pendekatan proses dan model PDCA termasuk elemen-elemen umum sebagaimana ditetapkan dalam ISO Guide 72. Dalam model ini semua manajemen dan proses pendukung yang diperlukan untuk mengelola dan meningkatkan kinerja suatu organisasi dalam melakukan bisnis yang terkait dengan bidang manajemen yang relevan sesuai dengan putaran PDCA.

Untuk mengintegrasikan sistem manajemen mutu dan sistem manajemen lingkungan dalam suatu organisasi, maka organisasi tersebut dapat menggunakan model sistem manajemen generik. Manajemen dan proses pendukung dapat diintegrasikan dengan mengembangkan prosedur terpadu, misalnya untuk pengembangan kebijakan, tujuan dan program, membangun kesadaran karyawan dan kaji ulang manajemen. Pada tingkat operasional, organisasi dapat menetapkan untuk setiap perbedaan proses, apakah karakteristik mutu atau aspek lingkungan yang ada. Jika demikian maka hal-hal tersebut dapat dikendalikan dengan menggunakan satu prosedur (prosedur tunggal) dan satu instruksi kerja ( instruksi kerja tunggal).

\section{HUBUNGAN ANTARA ELEMEN ISO 9001 DAN ISO 14001}

Dalam tabel 3 di bawah ini diperlihatkan hubungan antara elemen-elemen yang ada dalam standar ISO 9001 dan ISO 14001. Tujuan dari pembandingan kedua standar tersebut adalah untuk menunjukkan atau memperlihatkan 
bahwa kedua standar sistem manajemen tersebut dapat digunakan/diterapkan bersamasama dalam satu organisasi/industri.

Tabel 3 Perbandingan ISO 9001 dan ISO 14001

\begin{tabular}{|c|c|c|c|}
\hline \multicolumn{2}{|l|}{ ISO 9001} & \multicolumn{2}{|r|}{ ISO 14001} \\
\hline Sistem manajemen mutu (hanya judul) & 4 & 4 & $\begin{array}{l}\text { Persyaratan sistem manajemen ling- } \\
\text { kungan (hanya judul) }\end{array}$ \\
\hline Persyaratan umum & 4.1 & 4.1 & Persyaratan umum \\
\hline Persyaratan dokumentasi (hanya judul) & 4.2 & & \\
\hline Umum & 4.2 .1 & 4.4 .4 & Dokumentasi \\
\hline Panduan mutu & 4.2 .2 & & \\
\hline Pengendalian dokumen & 4.2 .3 & 4.4 .5 & Pengendalian dokumen \\
\hline Pengendalian rekaman & 4.2 .4 & 4.5 .4 & Pengendalian rekaman \\
\hline $\begin{array}{l}\text { Tanggung jawab manajemen (hanya } \\
\text { judul) }\end{array}$ & 5 & & \\
\hline Komitmen manajemen & 5.1 & $\begin{array}{l}4.2 \\
4.4 .1\end{array}$ & $\begin{array}{l}\text { Kebijakan lingkungan } \\
\text { Sumber daya, peran, tanggung jawab dan } \\
\text { kewenangan }\end{array}$ \\
\hline Fokus pelanggan & 5.2 & $\begin{array}{l}4.3 .1 \\
4.3 .2 \\
4.6\end{array}$ & $\begin{array}{l}\text { Aspek lingkungan } \\
\text { Persyaratan perundang-undangan dan } \\
\text { persyaratan lainnya } \\
\text { Kaji ulang manajemen }\end{array}$ \\
\hline Kebijakan mutu & 5.3 & 4.2 & Kebijakan lingkungan \\
\hline Perencanaan (hanya judul) & 5.4 & 4.3 & Perencanaan \\
\hline Tujuan mutu & 5.4 .1 & 4.3 .3 & Tujuan, target dan program \\
\hline Perencanaan sistem manajemen mutu & 5.4 .2 & 4.3 .3 & Tujuan, target dan program \\
\hline $\begin{array}{l}\text { Tanggung jawab, kewenangan dan } \\
\text { komunikasi (hanya judul) }\end{array}$ & 5.5 & & \\
\hline Tanggung jawab dan kewenangan & 5.5 .1 & 4.4 .1 & $\begin{array}{l}\text { Sumber daya, peran, tanggung jawab dan } \\
\text { kewenangan }\end{array}$ \\
\hline Wakil manajemen & 5.5 .2 & 4.4 .1 & $\begin{array}{l}\text { Sumber daya, peran, tanggung jawab dan } \\
\text { kewenangan }\end{array}$ \\
\hline Komunikasi internal & 5.5 .3 & 4.4 .3 & Komunikasi \\
\hline Kaji ulang manajemen (hanya judul) & 5.6 & & \\
\hline Umum & 5.6 .1 & 4.6 & Kaji ulang manajemen \\
\hline Masukan kaji ulang & 5.6 .2 & 4.6 & Kaji ulang manajemen \\
\hline Keluaran kaji ulang & 5.6 .3 & 4.6 & Kaji ulang manajemen \\
\hline Sumber daya manajemen (hanya judul) & 6 & & \\
\hline Ketentuan sumber daya & 6.1 & 4.4 .1 & $\begin{array}{l}\text { Sumber daya, peran, tanggung jawab dan } \\
\text { kewenangan }\end{array}$ \\
\hline Sumber daya manusia (hanya judul) & 6.2 & & \\
\hline Umum & 6.2 .1 & 4.4 .2 & Kompetensi, pelatihan dan kesadaran \\
\hline Kompetensi,kesadaran dan pelatihan & 6.2 .2 & 4.4 .2 & Kompetensi, pelatihan dan kesadaran \\
\hline Infrastruktur & 6.3 & 4.4 .1 & $\begin{array}{l}\text { Sumber daya, peran, tanggung jawab dan } \\
\text { kewenangan }\end{array}$ \\
\hline Lingkungan kerja & 6.4 & & \\
\hline Realisasi produk (hanya judul) & 7 & 4.4 & Implementasi dan operasi \\
\hline Perencanaan realisasi produk & 7.1 & 4.4 .6 & Pengendalian operasional \\
\hline $\begin{array}{l}\text { Proses terkait dengan pelanggan (hanya } \\
\text { judul) }\end{array}$ & 7.2 & & \\
\hline $\begin{array}{l}\text { Penetapan persyaratan terkait de-ngan } \\
\text { produk }\end{array}$ & 7.2 .1 & $\begin{array}{l}4.3 .1 \\
4.3 .2 \\
4.4 .6\end{array}$ & $\begin{array}{l}\text { Aspek lingkungan } \\
\text { Persyaratan perundang-undangan dan } \\
\text { persyaratan lainnya } \\
\text { Pengendalian operasional }\end{array}$ \\
\hline Kaji ulang persyaratan terkait dengan & 7.2 .2 & 4.3 .1 & Aspek lingkungan \\
\hline
\end{tabular}




\begin{tabular}{|c|c|c|c|}
\hline \multicolumn{2}{|l|}{ ISO 9001} & \multicolumn{2}{|r|}{ ISO 14001} \\
\hline produk & & 4.4 .6 & Pengendalian operasional \\
\hline Komunikasi pelanggan & 7.2 .3 & 4.4 .3 & Komunikasi \\
\hline $\begin{array}{l}\text { Desain dan pengembangan (hanya } \\
\text { judul) }\end{array}$ & 7.3 & & \\
\hline $\begin{array}{l}\begin{array}{l}\text { Perencanaan desain dan } \\
\text { bangan }\end{array} \\
\end{array}$ & 7.3 .1 & 4.4 .6 & Pengendalian operasional \\
\hline Masukan desain dan pengembangan & 7.3 .2 & 4.4 .6 & Pengendalian operasional \\
\hline Keluaran desain dan pengem-bangan & 7.3 .3 & 4.4 .6 & Pengendalian operasional \\
\hline Kaji ulang desain dan pengembanga & 7.3 .4 & 4.4 .6 & Pengendalian operasional \\
\hline Verifikasi desain dan pengembangan & 7.3 .4 & 4.4 .6 & Pengendalian operasional \\
\hline Validasi desain dan pengembangan & 7.3 .6 & 4.4 .6 & Pengendalian operasional \\
\hline $\begin{array}{l}\text { Pengendalian perubahan rancangan dan } \\
\text { pengembangan }\end{array}$ & 7.3 .7 & 4.4 .6 & Pengendalian operasional \\
\hline Pembelian (hanya judul) & 7.4 & & \\
\hline Proses pembelian & 7.4 .1 & 4.4 .6 & Pengendalian operasional \\
\hline Informasi pembelian & 7.4 .2 & 4.4 .6 & Pengendalian operasional \\
\hline Verifikasi produk yang dibeli & 7.4 .3 & 4.4 .6 & Pengendalian operasional \\
\hline $\begin{array}{l}\text { Produksi dan penyediaan jasa (hanya } \\
\text { judul) }\end{array}$ & 7.5 & & \\
\hline $\begin{array}{l}\text { Pengendalian produksi dan penye-diaan } \\
\text { jasa }\end{array}$ & 7.5 .1 & 4.4 .6 & Pengendalian operasional \\
\hline $\begin{array}{l}\text { Proses validasi untuk produksi dan } \\
\text { penyediaan jasa }\end{array}$ & 7.5 .2 & 4.4 .6 & Pengendalian operasional \\
\hline Identifikasi dan ketertelusuran & 7.5 .3 & & \\
\hline Milik pelanggan & 7.5 .4 & & \\
\hline Preservasi produk & 7.5 .5 & 4.4 .6 & Pengendalian operasional \\
\hline $\begin{array}{l}\text { Pengendalian sarana pemantauan dan } \\
\text { pengukuran }\end{array}$ & 7.6 & 4.5 .1 & Pemantauan dan pengukuran \\
\hline $\begin{array}{l}\text { Pengukuran, analisis dan perbaikan } \\
\text { (hanya judul) }\end{array}$ & 8 & 4.5 & Pemeriksaan \\
\hline Umum & 8.1 & 4.5 .1 & Pemantauan dan pengukuran \\
\hline $\begin{array}{l}\text { Pemantauan dan pengukuran (hanya } \\
\text { judul) }\end{array}$ & 8.2 & & \\
\hline Kepuasan pelanggan & 8.2 .1 & & \\
\hline Audit internal & 8.2 .2 & 4.5 .5 & Audit internal \\
\hline Proses pemantauan dan pengukuran & 8.2 .3 & $\begin{array}{l}4.5 .1 \\
4.5 .2\end{array}$ & $\begin{array}{l}\text { Pemantauan dan pengukuran } \\
\text { Evaluasi penaatan }\end{array}$ \\
\hline Pemantauan dan pengukuran produk & 8.2 .4 & $\begin{array}{l}4.5 .1 \\
4.5 .2 \\
\end{array}$ & $\begin{array}{l}\text { Pemantauan dan pengukuran } \\
\text { Evaluasi penaatan }\end{array}$ \\
\hline Pengendalian produk yang tidak sesuai & 8.3 & $\begin{array}{l}4.4 .7 \\
4.5 .3\end{array}$ & $\begin{array}{l}\text { Kesiagaan dan tanggap darurat } \\
\text { Ketidaksesuaian, tindakan perbaikan dan } \\
\text { tindakan pencegahan }\end{array}$ \\
\hline Analisis data & 8.4 & 4.5 .1 & Pemantauan dan pengukuran \\
\hline Perbaikan (hanya judul) & 8.5 & & \\
\hline Perbaikan berkesinambungan & 8.5 .1 & $\begin{array}{l}4.2 \\
4.3 .3 \\
4.6 \\
\end{array}$ & $\begin{array}{l}\text { Kebijakan lingkungan } \\
\text { Tujuan, target dan program } \\
\text { Kaji ulang manajemen }\end{array}$ \\
\hline Tindakan perbaikan & 8.5 .2 & 4.5 .3 & $\begin{array}{l}\text { Ketidaksesuaian, tindakan perbaikan dan } \\
\text { tindakan pencegahan }\end{array}$ \\
\hline Tindakan pencegahan & 8.5 .3 & 4.5 .3 & $\begin{array}{l}\text { Ketidaksesuaian, tindakan perbaikan dan } \\
\text { tindakan pencegahan }\end{array}$ \\
\hline
\end{tabular}

Dari tabel 3 di atas dapat dilihat bahwa banyak elemen yang terdapat dalam standar ISO 9001 sama dengan elemen yang ada dalam ISO 14001. Oleh karena itu maka kedua standar tersebut tentunya dapat diintegrasikan menjadi satu standar saja yaitu menjadi standar tentang "persyaratan sistem manajemen mutu dan/atau lingkungan". Dengan demikian maka dalam suatu organisasi atau industri yang ingin menerapkan standar ISO 9001 dan ISO 14001 
secara bersamaan akan lebih mudah dan efisien.

\section{KESIMPULAN}

Berdasarkan pada uraian tersebut di atas, maka dapat disimpulkan bahwa dua standar sistem manajemen (ISO 9001 dan ISO 14001) mempunyai konsep dasar yang mirip (similar) yang digunakan sebagai alat untuk membangun kebijakan dan tujuan suatu organisasi di bidang tertentu.

Disamping itu banyak elemen yang terdapat dalam standar ISO 9001 sama dengan elemen yang ada dalam ISO 14001, sehingga kedua standar tersebut dapat diterapkan secara bersamaan dalam suatu organisasi atau industri. Untuk membantu organisasi/industri dalam menerapkan dua standar sistem manajemen tersebut secara bersamaan, sebaiknya disediakan suatu buku petunjuk atau buku panduan, sehingga organisasi/industri tidak akan menemui kesulitan dalam menerapkannya.

Standar ISO 9001 dan ISO 14001 tersebut juga mempunyai dasar dan pendekatan yang sama, dimana kedua standar tersebut merupakan hasil dari proses konsensus yang telah disepakati secara internasional.

Standar ISO 9001 dan ISO 14001 tersebut pada prinsipnya dapat diintegrasikan atau digabungkan menjadi satu standar sistem manajemen yang terpadu, dengan menggunakan model generik berdasarkan pada prinsip-prinsip umum dan elemen-elemen standar sistem manajemen. Model ini adalah suatu model dengan menggabungkan pendekatan proses dan model PDCA.

Dengan dapat diterapkannya dua standar sistem manajemen secara bersamaan ini, maka organisasi/industri yang ingin menerapkan standar di dalam organisasi/industrinya, maka akan menjadi lebih efektif dan efisien baik dari segi waktu maupun biaya.

\section{DAFTAR PUSTAKA}

1. ISO 9001: 2000, Persyaratan Sistem Manajemen Mutu

2. ISO 14001: 2004, Persyaratan Sistem Manajemen Lingkungan

3. ISO Management System, January-February 2004

\section{BIODATA}

Suminto, dilahirkan di Sukoharjo pada tanggal 10 Desember 1954. Penulis menamatkan pendidikan di Akademi Industri Yogyakarta pada tahun 1978 dan menyelesaikan Post graduate Diploma bidang Environmental Science and Technology dari Delft, Belanda tahun 1992. Saat ini penulis aktif sebagai peneliti di lingkungan BSN dengan bidang keahlian ISO 9000 dan ISO 14000. 